\title{
The therapeutic potential of truffle fungi: a patent survey
}

\author{
Małgorzata Gajos ${ }^{1 *}$, Florian Ryszka², Joerg Geistlinger ${ }^{3}$ \\ 'Department of Biomedical Computer Systems, University of Silesia, Będzińska 39, 41-200 Sosnowiec, Poland \\ 2 Pharmaceutical Research and Production Plant "Biochefa", Kasztanowa 3, 41-205 Sosnowiec, Poland \\ ${ }^{3}$ Department of Agriculture, Ecotrophology and Landscape Development, Anhalt University of Applied Sciences, Strenzfelder Allee 28, 06406 \\ Bernburg, Germany
}

\section{Abstract}

The purpose of this article is to research and retrieve patent information regarding the therapeutic use of truffles. Truffles have a unique value as a foodstuff and impact positively on human health and well-being. They are applied in such industries as the pharmaceutical industry and the cosmetic industry. Patent documentation available in the Espacenet network and the Patentscope service were analyzed by key word and patent specifications were examined to describe state of the art and to identify scientific research trends in therapeutic applications of truffles. Medicinal properties of truffles such as the anticancer or cardiovascular effect, a reduction in blood lipids, immunological resistance and increased energy were identified. Other therapeutic benefits include sedative action, prevention of hormonal imbalances in women, pre-menopause symptom relief, senile urethritis and prostate disorders, sleep disorders and increased absorption of calcium from milk. Truffles can also be used to alleviate symptoms of milk intolerance such as diarrhoea or bloating, to ease rheumatic pains and to treat and prevent further development or recurrence of senile cataract.

Keywords: truffle fungi; Tuber; therapeutic potential of truffles; patent survey

\section{Introduction}

The number of patents granted annually to inventions is an important indicator of technological development [1]. In order to obtain patent protection, each invention should

\footnotetext{
*Corresponding author. Email: malgorzata.gajos@us.edu.pl

Handling Editor: Maria Rudawska
} 
be characterized by patentability, determined by novelty, inventive step and industrial application.

This article reviews patent research into truffle (Tuber)-related inventions. It addresses the important role of truffles in the food industry and documents their positive effects on human health and well-being as well as their usefulness in the pharmaceutical industry. However, truffles are some of the most expensive organic products in the world due to limited resources and difficulties in obtaining them.

Patent research is a set of activities consisting of searching and analyzing patent information. It comprises searches of patent literature and documentation that are further analyzed for relevant information. Conclusions based on patent research can be successfully used to evaluate practicability of applying for patent protection for a specific solution, to provide solutions of international technical standard permitting patent protection, to select scientific research directions, to secure presumption that a technical solution does not infringe on patent rights of third persons and to use known solutions when implementing research objectives within legally permissible imitation.

A recent publication by Gajos and Hilszczańska [2] surveys the state of the art and research interests regarding truffles. The purpose of the present article was to analyze truffle patent information. Patent documentation was researched through patent databases and patent specifications. Patented and patent-applied developments as well as specific thematic scopes of implemented invention proposals were explored, with the scientific and technical information being studied. Such patent research primarily evaluates the state of the art in truffle research.

There are more than 100 truffle species belonging to the Tuberales worldwide. The most economically significant truffles belong to the genus Tuber and grow, e.g., in Southern Europe, particularly in northern Spain, Italy and Greece, in southern France and Croatia.

Truffles contain a variety of biochemical components, including steroids, pheromones, flavonoide, anthocyanine, carotenoide, oligosaccharide and volatile organic compounds (VOCs) such as dimethyl-sulfide and -bisulfide, butanedione, butyrate, hexenone, ethyl-, methyl- and propylphenole and methylthiomethane. To date they are widely unexplored and unexploited resources that have a therapeutic potential as they contain antioxidant, antimicrobial, antiviral, antimutagenic, anticarcinogenic, immune-modulating, hepatoprotective, antidepressant and sedative bioactive substances [3].

Truffles have protective effects due to their antioxidant [4] and antiradical properties [5]. They contain a variety of phenolic substances, which are very efficient scavengers of peroxyl radicals [4]. A previous report showed the expression of some 120 antioxidant enzymes [6]. Correspondingly, truffles show strong inhibition of lipid oxidation, which indicates effective antioxidant activity [7]. The antioxidant-rich aqueous extract of desert truffle Terfezia claveryi was demonstrated to have a very powerful hepatoprotective activity when evaluated in rats using the potent hepatotoxin carbon tetrachloride [8].

A few studies discuss the antimicrobial importance of truffles $[9,10]$. Activity against Gram(-) and Gram(+) bacteria has been reported [11]. Truffle extracts showed in-vitro activity against Chlamydia trachomatis, Staphylococcus aureus and Pseudomonas aeruginosa. Antiviral activity was reported by Hussan and Al-Ruqaie [12].

Antimutagenicity was studied with Tuber aestivum (summer truffle) extracts and irradiation of bacteria with the application of the mutagens nitroflurene and sodium azide [13]. Anti-inflammatory effects were determined as inhibitory effects on cyclooxygenase- 2 
(COX2), an enzyme that plays an important role in the inflammatory process [14]. Intracellular polysaccharides isolated from the fruiting body of Tuber sinense have been shown to exhibit immuno-modulation and antitumour activities [15]. The influence on tumour cell growth was detected by Ferreira et al. [16] and $\mathrm{Ng}$ and Wong [17]. Possible bioactive substances were classified as quinines, isoflavones, steroids, ceramides and catechols.

A new polyhydroxy sterol glycoside named tuberoside has been isolated from fruiting bodies of Tuber indicum. These compounds are assumed to be structural constituents of cellular membranes and precursors of steroid hormones that antagonise anxiety and act as sedatives by positively modulating GABA receptors [18].

A genetic analysis of Tuber progressed substantially with the publication of the total genome sequence of Tuber melanosporum (black perigord truffle) [19]. It is by far the largest genome sequence (125 MB) ever obtained from an ascomycete fungus but, in contrast, only 7500 protein-coding genes were found, with large gene families almost completely missing. Moreover, simple sequence repeats are highly abundant in this genome [20], which offers an excellent opportunity for the development of molecular markers that can be applied in further genetic analyses of various species or genotypes. Information on the transcriptome exists from Tuber borchii (Bianchetto truffle) regarding differentially expressed genes in vegetative mycelium and fruiting bodies [21].

Genomic information regarding the genus Tuber is clearly quite abundant and genes for biochemical pathways involved in the synthesis of bioactive molecules (anti-inflammatory, antioxidant, etc.) and VOCs that are responsible for the different tastes, odors, scents and aromas of Tuber could be identified based on it. Truffles can be commercialized as food additives or flavors as well as fragrance in cosmetics industries [22].

Furthermore, it has been shown that isolated Tuber genes can be expressed in heterologous expression systems like Escherichia coli and yeast [23,24]. This is a prerequisite for the biotechnological production of bioactive compounds independent of natural truffle grounds. Due to a decline in natural Tuber populations, caused by intensive collection of fruiting bodies for cooking, attempts have been made to cultivate Tuber species as fermentation mycelia. It has been shown that mycelia grown in-vitro had elevated sterol content as compared to fruiting bodies collected from the wild [25].

\section{Material and methods}

Espacenet and Patentscope as well as patent specifications for submitted and patented truffle-related developments were used in this study. In October 1998, the European Patent Office (EPO) launched esp@cenet, a network of free patent databases containing patent documents (patents and patent applications) from Europe, Japan, the U.S. and the World Intellectual Property Organization (WIPO) [26]. Patentscope (WIPO) is a free search service offered by the World Intellectual Property Organization. It includes many national patent collections, including some of rare coverage.

Patent specifications are basic sources of scientific-technical information. They are carriers of technical, legal, economic, sociological and organizational information as well as personal information regarding inventors. A patent specification is a document that consists of a bibliographical part, a description of the invention, patent claims and illustrations [27]. 
Codes found in patent descriptions in brackets or circles are designed to facilitate their drafting, information searches and patent research performance. International unification of the bibliographical description is independent of the language in which the bibliographical description is formulated as well as of the composition and sequence of factors, which determine a country-specific patent system. Associated Standards ST. recommendations and guidelines as elaborated by the WIPO are published in the "Handbook on industrial property information and documentation" (e.g. ST.3 two-letter codes for the representation of states, other entities and organizations, e.g. CN - China, EP - European Patent Office, WO World Intellectual Property Organization; ST.9 bibliographical data on and relating to patents; ST.16 identification of different kinds of patent documents, e.g., a first publication level patent application, dependence on national system could also be e.g. A1), B - second publication level patent specification, dependence on national system could also be e.g. B1) [28].

Patenting solutions for truffles can be recognized based on analyses of inventions, patent claims and drawings.

The classification code in the bibliographical part, which is also known as the international patent classification (IPC), consists of the symbol of a section (A-H). Each section is subdivided into classes (each class symbol consists of the section symbol followed by a two-digit number). Each class comprises one or more subclasses (each subclass symbol consists of the class symbol followed by a capital letter). Each class and subclass has a title. Each subclass is broken down into subdivisions referred to as "groups" which are either main groups or subgroups [29].

Bibliographical data studies of patent specifications can help set research directions, e.g. to classify objects according to the IPC, and establish countries, companies and investors leading in the field of truffles or names of internationally renowned experts who can be patent creators.

Patent research is mainly conducted by patent offices (in connection with the consideration of patent applications) as well as patent attorneys and invention services (in connection with technical innovations being applied for patenting and implementation of new technology and service products). In order to recognize the state of the art and to delineate scientific research directions, patent research can also be performed by scientific practitioners, especially when there is access to Internet patent databases. The advantage of electronic databases is that they offer easy access to thematic information by keyword search. Patent research includes: $(i)$ basic research comprising patent discernment (stateof-the-art research), presumption that a given technical solution does not infringe on patent rights of third persons, patentability research and comprehensive patent research; (ii) special research for technology development planning and forecasting, standardisation papers, foreign trade and innovations development purposes.

The article presents research into the state-of-the-art in relation to truffles. Such studies should precede any scientific research of technical nature. The objective of patent research is to present developments in a specific domain of technology and technical advances. The time scope is based on the development rate of a specific discipline: five to six years in rapidly growing domains and slightly more for domains which grow more slowly. Since this article is meant to recognize the broad status of truffle-related developments, no time constraints were introduced and Espacenet and Patentscope bases were searched in their entirety. 
The following patent research methods are distinguished: object (by classification or keyword), subject (by company name or inventor's personal name), patents obtained for the same invention in different countries (by priority dates), mixed (using elements of the above methods). This article uses the object method; research object is classified according to the IPC and keyword search was used for a research topic. An analysis was run for identified patent specifications and the research status was determined. Next the subject method was applied. The country of origin was established for leading institutions in the research domain covered by this article. Finally, possible research directions were set for truffle research.

\section{Results and discussion}

The international patent classification represents the whole body of knowledge, which may be regarded as proper to the field of patents for invention. The following sections and classes were investigated in this article:

(i) A (human necessities) - A01 (agriculture, forestry, animal husbandry, hunting, trapping, fishing); A23 (foods or foodstuffs, their treatment); A61 (medical or veterinary science, hygiene);

(ii) C (chemistry; metallurgy) - C07 (organic chemistry); C11 (animal or vegetable oils, fats, fatty substances or waxes, fatty acids thereof, detergents, candles); C12 (biochemistry, beer, spiritus, wine, vinegar, microbiology, enzymology, mutation or genetic engineering);

(iii) G (physics) - G01 (measuring, testing).

As of December 2012, a total of 29 documents regarding truffle inventions (patent applications and patent specifications or only patent applications) concerning medicine, health, pharmaceuticals and diet supplements were found. Patent application (A, A1) follows formal and legal research, patent specification (B) follows formal, legal and substantive research (patentability). Results are presented in a table (Tab. 1). Patent information regarding all twenty nine inventions belongs to the state of the art but only six inventions were granted a patent (with five patents belonging to Chinese investors and one belonging to an Italian investor); the procedure has not been closed for one patent yet and the remaining inventions were not granted a patent.

Titles of inventions and sources of patent applications or patent specifications are given in a table (Tab. 2).

\section{Anticancer properties (Invention 5)}

One of the many benefits of truffles used in the pharmaceutical industry and medicine is their anticancer action as reflected in the inhibition of tumor cell growth. Medical properties of wild truffles are stronger as compared to those found in other species of fungi such as in Ganoderma lucidum (lingzhi mushroom) and Cordyceps militaris (scarlet caterpillar club mushroom). The process of preparing a natural product from wild truffles, black truffle (T. melanosporum) and brown truffle, comprises adding the aforementioned fungal species to distilled water, inactivation at $121-125^{\circ} \mathrm{C}$ under a pressure of $1 \mathrm{~atm}$. for 2 to 3 hours followed by addition of alcohol and uniform mixing. The solution is kept 
Tab. 1 Patent research about truffles in Espacenet and Patentscope database.

\begin{tabular}{|c|c|c|c|c|c|c|c|}
\hline 总 & 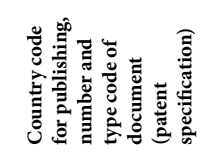 & 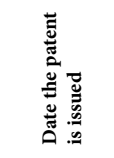 & 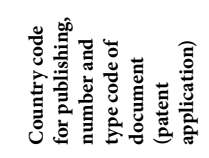 & 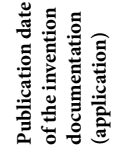 & 总 & 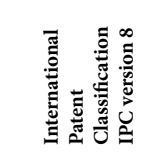 & \\
\hline \multicolumn{8}{|c|}{ Medicine and health - pharmaceuticals, diet supplements (29) } \\
\hline 1 & - & - & $\mathrm{CN} 102224872(\mathrm{~A})$ & 2011-10-26 & 2011-04-28 & $\begin{array}{l}\mathrm{A} 23 \mathrm{~F} 5 / 24 \\
\mathrm{~A} 23 \mathrm{~F} 5 / 38 \\
\mathrm{~A} 23 \mathrm{~F} 5 / 40\end{array}$ & $\mathrm{CN}$ \\
\hline 2 & CN102145019 (B) & 2012-10-10 & CN102145019 (A) & 2011-08-10 & 2011-03-29 & $\begin{array}{l}\text { A23C } 9 / 152 \\
\text { A23L1/29 } \\
\text { A23L2/38(+31) }\end{array}$ & $\mathrm{CN}$ \\
\hline 3 & - & - & CN101965972 (A) & 2011-02-09 & 2010-10-12 & $\begin{array}{l}\mathrm{A} 23 \mathrm{~L} 1 / 20 \\
\mathrm{~A} 23 \mathrm{~L} 1 / 28 \\
\mathrm{~A} 23 \mathrm{~L} 1 / 29\end{array}$ & $\mathrm{CN}$ \\
\hline 4 & - & - & CN101911989 (A) & $2010-12-15$ & 2010-08-03 & $\mathrm{A} 23 \mathrm{~F} 3 / 14$ & $\mathrm{CN}$ \\
\hline 5 & CN101732362 (B) & 2011-06-15 & CN101732362 (A) & 2010-06-16 & 2008-11-21 & $\begin{array}{l}\text { A61K36/06 } \\
\text { A61P35/00 } \\
\text { A61P37/04 }\end{array}$ & $\mathrm{CN}$ \\
\hline 6 & - & - & CN101313920 (A) & $2008-12-03$ & 2008-06-25 & $\begin{array}{l}\text { A23L1/30 } \\
\text { A61K36/06 } \\
\text { A61P13/02(+3) }\end{array}$ & $\mathrm{CN}$ \\
\hline 7 & - & - & CN101268831 (A) & 2008-09-24 & 2008-04-08 & $\begin{array}{l}\text { A23L1/28 } \\
\text { A23L1/29 } \\
\text { A61K36/06(+3) }\end{array}$ & $\mathrm{CN}$ \\
\hline 8 & IT1190435 (B) & $1988-02-16$ & - & - & $1985-12-13$ & $\mathrm{~A} 23 \mathrm{~L}$ & IT \\
\hline 9 & - & - & CN102551066 (A) & 2012-07-11 & 2012-03-26 & $\begin{array}{l}\text { A23L1/28 } \\
\text { A23L1/29 }\end{array}$ & $\mathrm{CN}$ \\
\hline 10 & - & - & CN102334549 (A) & $2012-02-01$ & 2011-06-08 & $\mathrm{A} 23 \mathrm{C} 9 / 12$ & $\mathrm{CN}$ \\
\hline 11 & CN102250709 (B) & 2012-12-12 & CN102250709 (A) & 2011-11-23 & 2011-06-08 & $\begin{array}{l}\mathrm{C} 12 \mathrm{G} 1 / 022 \\
\mathrm{C} 12 \mathrm{R} 1 / 645\end{array}$ & $\mathrm{CN}$ \\
\hline 12 & - & - & CN102224853 (A) & 2011-10-26 & 2011-06-08 & $\begin{array}{l}\text { A23D9/007 } \\
\text { A23D9/04 } \\
\text { A23L1/226 }\end{array}$ & $\mathrm{CN}$ \\
\hline 13 & - & - & CN102090455 (A) & 2011-06-15 & $2010-09-25$ & $\begin{array}{l}\text { A23C } 9 / 152 \\
\text { A23C } 9 / 18\end{array}$ & $\mathrm{CN}$ \\
\hline 14 & - & - & CN102771860 (A) & 2012-11-14 & $2012-07-20$ & $\begin{array}{l}\mathrm{A} 01 \mathrm{G} 1 / 04 \\
\mathrm{~A} 23 \mathrm{~L} 1 / 28 \\
\mathrm{~A} 23 \mathrm{~L} 1 / 29 \\
\mathrm{~A} 23 \mathrm{~L} 2 / 38\end{array}$ & $\mathrm{CN}$ \\
\hline 15 & - & - & CN102771773 (A) & 2012-11-14 & $2012-07-20$ & $\begin{array}{l}\text { A01G1/04 } \\
\text { A23L1/28 } \\
\text { A23L1/30 }\end{array}$ & $\mathrm{CN}$ \\
\hline 16 & & & CN102771857 (A) & 2012-11-14 & 2012-07-20 & $\begin{array}{l}\mathrm{A} 23 \mathrm{~L} 1 / 28 \\
\mathrm{~A} 23 \mathrm{~L} 2 / 38 \\
\mathrm{~A} 23 \mathrm{~L} 2 / 52\end{array}$ & $\mathrm{CN}$ \\
\hline 17 & & & CN102771855 (A) & 2012-11-14 & 2012-07-20 & $\begin{array}{l}\mathrm{A} 01 \mathrm{G} 1 / 04 \\
\mathrm{~A} 23 \mathrm{~L} 1 / 29 \\
\mathrm{~A} 23 \mathrm{~L} 2 / 38\end{array}$ & $\mathrm{CN}$ \\
\hline 18 & & & CN102771762 (A) & 2012-11-14 & $2012-07-20$ & $\begin{array}{l}\mathrm{A} 01 \mathrm{G} 1 / 04 \\
\mathrm{~A} 23 \mathrm{~L} 1 / 28 \\
\mathrm{~A} 23 \mathrm{~L} 1 / 29\end{array}$ & $\mathrm{CN}$ \\
\hline 19 & & & CN102640820 (A) & $2012-08-22$ & 2012-04-25 & $\mathrm{A} 23 \mathrm{~F} 3 / 14$ & $\mathrm{CN}$ \\
\hline 20 & & & CN102599514 (A) & $2012-07-25$ & 2012-03-26 & A23L1/29 & $\mathrm{CN}$ \\
\hline 21 & CN102224873 (B) & 2012-12-05 & $\mathrm{CN} 102224873(\mathrm{~A})$ & 2011-10-26 & 2011-05-06 & $\begin{array}{l}\mathrm{A} 23 \mathrm{~F} 5 / 40 \\
\mathrm{~A} 23 \mathrm{~F} 5 / 42\end{array}$ & $\mathrm{CN}$ \\
\hline 22 & CN102224925 (B) & $2012-12-12$ & CN102224925 (A) & 2011-10-26 & 2011-05-06 & $\begin{array}{l}\text { A23L1/29 } \\
\text { C12N1/14 }\end{array}$ & $\mathrm{CN}$ \\
\hline 23 & & & CN102199547 (A) & 2011-09-28 & 2011-04-28 & $\begin{array}{l}\mathrm{C} 12 \mathrm{~N} 1 / 14 \\
\mathrm{C} 12 \mathrm{R} 1 / 645\end{array}$ & $\mathrm{CN}$ \\
\hline
\end{tabular}




\begin{tabular}{|c|c|c|c|c|c|c|c|}
\hline 产 & 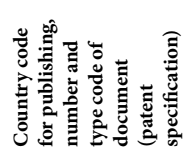 & 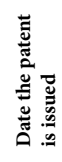 & 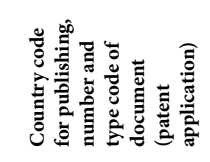 & 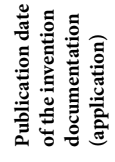 & 总 & 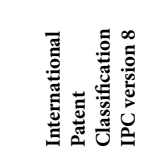 & 营 \\
\hline 24 & & & CN102058728 (A) & 2011-05-18 & 2010-11-16 & $\begin{array}{l}\text { A23F3/14 } \\
\text { A23L1/29 } \\
\text { A61K35/64(+9) }\end{array}$ & $\mathrm{CN}$ \\
\hline 25 & & & CN101856370 (A) & 2010-10-13 & 2010-07-07 & $\begin{array}{l}\text { A23L1/29 } \\
\text { A61K36/068 } \\
\text { A61K36/28(+7) }\end{array}$ & $\mathrm{CN}$ \\
\hline 26 & & & CN101892143 (A) & 2010-11-24 & 2009-05-20 & $\mathrm{C} 12 \mathrm{G} 3 / 04$ & $\mathrm{CN}$ \\
\hline 27 & & & JP2002249438 (A) & 2002-09-06 & $2001-02-22$ & $\begin{array}{l}\text { A23L1/30 } \\
\text { A61Q1/2 }\end{array}$ & $\mathrm{JP}$ \\
\hline 28 & & & JP2002173441 (A) & $2002-06-21$ & $2000-09-27$ & $\begin{array}{l}\text { A23L1/30 } \\
\text { A61Q 19/10 }\end{array}$ & $\mathrm{JP}$ \\
\hline 29 & & & $\begin{array}{l}\text { US20120039927 A1 } \\
\text { WO2012021466 }\end{array}$ & $2012-02-16$ & & $\begin{array}{l}\text { A61P27/12 } \\
\text { A61K 36/062 }\end{array}$ & US \\
\hline
\end{tabular}

Source: the author's eleboration based on Espacenet and Patentscope databases.

overnight at 4 to $10^{\circ} \mathrm{C}$, then subjected to centrifugation 1000 to $1200 \mathrm{rpm}, 10-15 \mathrm{~min}$, and the resulting supernatant is lyophilized.

\section{Cardiovascular effect (Invention 4, 19)}

Another example of the operation of active substances in fungi is their effect on the cardiovascular system. Tea extracts composed of truffles, lingzhi mushrooms and black beans can be applied to prevent and treat cardiovascular and cerebrovascular diseases. The preparation method includes: weighing 15-20 parts of sun-dried tea, 2-6 part truffles, 2-5 part lingzhi mushrooms and 2-5 parts of black beans, followed by ethanol extraction of fungi and black beans, washing the extract with water, combining the washed extracts with tea and fermentation (Invention 4). Pu-erh tea compositions containing Arctium lappa (greater burdock 40-60\%) and truffles (20-40\%) are used to lower blood pressure. These teas are brewed for 3 minutes in $250 \mathrm{ml}$ of water at $93^{\circ} \mathrm{C}$. One bag may be brewed from 3 to 5 times (Invention 19).

\section{Reduction in blood fats (Invention 12, 19, 24)}

$\mathrm{Pu}$-erh tea compositions containing greater burdock and truffles also demonstrate an effect of lowering blood lipid levels (Invention 19). A similar behavior is demonstrated by edible oil containing vegetable oil or animal fats and truffle-derived oil. The volume ratio of the above-mentioned fats/oils in the raw material is 1:0.1-1 (Invention 12). A preparation containing red tea and truffles lowers the level of blood fats (Invention 24) and can also be used as edible oil the composition of which is based on vegetable or animal fats and fat derived from truffles. The volume ratio of the above-mentioned fats in the raw material is 1:0.1-1 (Invention 12). A preparation containing red tea and truffles has also been proven to have this effect. Raw material of this preparation contains 1-20 parts (by 
Tab. 2 Titles of truffle-related inventions based on Espacenet and Patentscope databases.

Inv. No. Title of invention

Source of patent information regarding invention

A/B

Medicine and health - pharmaceuticals, diet supplements (29)

$1 \quad$ Health food with truffles and coffee beans as raw materials

2 Medicinal composition containing truffles, vitamins and mineral substances

3 Health-care food made of truffles and beans

$4 \quad$ Truffle health-care tea and preparation method thereof

5 Application of wild truffle in preparing medicine with anticancer and immunological functions

6 Application of truffle extract in preparing foods, medicine for treating endocrine dyscrasia diseases

7 Truffle hydrophilic solvent extract and application of the same in preparing food, health food, and medicament for treating prostate gland disease etc.

8 Solid truffle product

$9 \quad$ Health-care food containing maca, cordyceps and truffle

10 Dairy product with raw materials containing truffle

11 Beverage prepared from raw material containing truffle

12 Edible oil with raw material containing truffle oil

13 Truffle-containing milk

14 Truffle health drink prepared by liquid-submerged fermentation and preparation method of truffle health drink
http://worldwide.espacenet.com/publicationDetails/

A biblio adjacent $=$ true $\&$ locale $=$ en_EP $\& F T=D \&$ date $=2$ $0111026 \& \mathrm{CC}=\mathrm{CN} \& \mathrm{NR}=102224872 \mathrm{~A} \& \mathrm{KC}=\mathrm{A}$

http://worldwide.espacenet.com/publicationDetails/ B biblio adjacent $=$ true $\&$ locale $=$ en_EP $\& F T=D \&$ date $=2$ $0110810 \& C C=\mathrm{CN} \& \mathrm{NR}=102145019 \mathrm{~A} \& \mathrm{KC}=\mathrm{A}$

http://worldwide.espacenet.com/publicationDetails/ biblio adjacent $=$ true $\&$ locale $=$ en_EP $\& F T=D \&$ date $=2$ $0110209 \& \mathrm{CC}=\mathrm{CN} \& \mathrm{NR}=101965972 \mathrm{~A} \& \mathrm{KC}=\mathrm{A}$

http://worldwide.espacenet.com/publicationDetails/ biblio ?adjacent $=$ true\&locale $=$ en_EP \&FT $=\mathrm{D} \&$ date $=2$ $0101215 \& C C=C N \& N R=101911989 A \& K C=A$

http://worldwide.espacenet.com/publicationDetails/ biblio ?adjacent $=$ true \&locale $=$ en_EP\&FT $=$ D\&date $=2$ $0100616 \& C C=\mathrm{CN} \& \mathrm{NR}=101732362 \mathrm{~A} \& \mathrm{KC}=\mathrm{A}$

http://worldwide.espacenet.com/publicationDetails/ biblio adjacent $=$ true $\&$ locale $=$ en_EP $\& F T=D \&$ date $=2$ $0081203 \& \mathrm{CC}=\mathrm{CN} \& \mathrm{NR}=101313920 \mathrm{~A} \& \mathrm{KC}=\mathrm{A}$

http://worldwide.espacenet.com/publicationDetails/ biblio? adjacent $=$ true $\&$ locale $=$ en_EP $\& F T=D \&$ date $=2$ $0080924 \& \mathrm{CC}=\mathrm{CN} \& \mathrm{NR}=101268831 \mathrm{~A} \& \mathrm{KC}=\mathrm{A}$

http://worldwide.espacenet.com/publicationDetails/ B biblio adjacent $=$ true $\&$ locale $=$ en_EP $\& F T=D \&$ date $=1$ 9880216\&CC $=\mathrm{IT} \& \mathrm{NR}=1190435 \mathrm{~B} \& \mathrm{KC}=\mathrm{B}$

http://worldwide.espacenet.com/publicationDetails/ biblio adjacent $=$ true $\&$ locale $=$ en_EP $\& F T=D \&$ date $=2$ 0120711\&CC $=\mathrm{CN} \& \mathrm{NR}=102551066 \mathrm{~A} \& \mathrm{KC}=\mathrm{A}$

http://worldwide.espacenet.com/publicationDetails/ biblio ?adjacent $=$ true $\&$ locale $=$ en_EP\&FT $=$ D\&date $=2$ $0120201 \& \mathrm{CC}=\mathrm{CN} \& \mathrm{NR}=102334549 \mathrm{~A} \& \mathrm{KC}=\mathrm{A}$

http://worldwide.espacenet.com/publicationDetails/ biblio ?adjacent $=$ true $\&$ locale $=$ en_EP $\& F T=D \&$ date $=2$ $0111123 \& C C=C N \& N R=102250709 A \& K C=A$

http://worldwide.espacenet.com/publicationDetails/ biblio ?adjacent $=$ true $\&$ locale $=$ en_EP $\& F T=D \&$ date $=2$ $0111026 \& C C=C N \& N R=102224853 A \& K C=A$

http://worldwide.espacenet.com/publicationDetails/ biblio ?adjacent $=$ true $\&$ locale $=$ en_EP\&FT $=$ D\&date $=2$ 0110615\&CC $=\mathrm{CN} \& \mathrm{NR}=102090455 \mathrm{~A} \& \mathrm{KC}=\mathrm{A}$

http://worldwide.espacenet.com/publicationDetails/ biblio? $\mathrm{DB}=$ worldwide.espacenet.com $\& \mathrm{II}=5 \& \mathrm{ND}=3$

\&adjacent $=$ true \&locale $=$ en_EP $\& F T=D \&$ date $=20121$ $114 \& \mathrm{CC}=\mathrm{CN} \& \mathrm{NR}=102771860 \mathrm{~A} \& \mathrm{KC}=\mathrm{A}$ 
Inv. No. Title of invention

15

Truffle health-care product containing traditional Chinese medicine extractive and preparation method thereof

16 Truffle health-care drink prepared through liquid submerged fermentation and preparation method of truffle health-care drink prepared through liquid submerged fermentation

17 Truffle health care product and preparation method thereof

18 Truffle health-care product prepared through liquid submerged fermentation and preparation method of truffle health-care product prepared through liquid submerged fermentation

19 Formula of health tea with truffle and burdock and production method of health tea with truffle and burdock

Health food containing maca and truffle

21 Method for preparing food from raw materials comprising coffee beans

Method for preparing food from truffle and coffee beans as raw materials

Truffle fermentation culture medium and preparation method

24 Medicament with raw materials containing red tea and truffle

Medicine combination capable of of truffle

Source of patent information regarding invention

A/B

http://worldwide.espacenet.com/publicationDetails/

A

biblio ?DB=worldwide.espacenet.com $\& \mathrm{II}=6 \& \mathrm{ND}=3$

\&adjacent $=$ true $\&$ locale $=$ en_EP $\& \mathrm{FT}=\mathrm{D} \&$ date $=20121$

$114 \& \mathrm{CC}=\mathrm{CN} \& \mathrm{NR}=102771773 \mathrm{~A} \& \mathrm{KC}=\mathrm{A}$

http://worldwide.espacenet.com/publicationDetails/ biblio? $\mathrm{DB}=$ worldwide.espacenet.com $\& \mathrm{II}=7 \& \mathrm{ND}=3$

\&adjacent $=$ true\&locale $=$ en_EP\&FT $=$ D\&date $=20121$

$114 \& \mathrm{CC}=\mathrm{CN} \& \mathrm{NR}=102771857 \mathrm{~A} \& \mathrm{KC}=\mathrm{A}$

A

A biblio ?BB=worldwide.espacenet.com $\& \mathrm{II}=8 \& \mathrm{ND}=3$ \&adjacent $=$ true $\&$ locale $=$ en_EP $\& F T=D \&$ date $=20121$ $114 \& \mathrm{CC}=\mathrm{CN} \& \mathrm{NR}=102771855 \mathrm{~A} \& \mathrm{KC}=\mathrm{A}$

http://worldwide.espacenet.com/publicationDetails/ biblio? $\mathrm{DB}=$ worldwide.espacenet.com \&II $=9 \& \mathrm{ND}=3$ \&adjacent $=$ true\&locale $=$ en_EP\&FT $=\mathrm{D} \&$ date $=20121$ $114 \& \mathrm{CC}=\mathrm{CN} \& \mathrm{NR}=102771762 \mathrm{~A} \& \mathrm{KC}=\mathrm{A}$

http://worldwide.espacenet.com/publicationDetails/ biblio? $\mathrm{DB}=$ worldwide.espacenet.com $\& \mathrm{II}=14 \& \mathrm{ND}=3$ \&adjacent $=$ true $\&$ locale $=$ en_EP $\& F T=D \&$ date $=20120$ $822 \& C C=\mathrm{CN} \& \mathrm{NR}=102640820 \mathrm{~A} \& \mathrm{KC}=\mathrm{A}$

http://worldwide.espacenet.com/publicationDetails/ biblio? $\mathrm{DB}=$ worldwide.espacenet.com $\& \mathrm{II}=15 \& \mathrm{ND}=3$ \&adjacent $=$ true\&locale $=$ en_EP \&FT $=$ D\&date $=20120$ 725\&CC $=\mathrm{CN} \& \mathrm{NR}=102599514 \mathrm{~A} \& \mathrm{KC}=\mathrm{A}$

http://worldwide.espacenet.com/publicationDetails/ biblio? $\mathrm{DB}=$ worldwide.espacenet.com $\& \mathrm{II}=21 \& \mathrm{ND}=3$ \&adjacent $=$ true\&locale $=$ en_EP \&FT $=$ D\&date $=20111$ 026\&CC $=\mathrm{CN} \& \mathrm{NR}=102224873 \mathrm{~A} \& \mathrm{KC}=\mathrm{A}$

http://worldwide.espacenet.com/publicationDetails/ biblio? $\mathrm{DB}=$ worldwide. espacenet.com $\& \mathrm{II}=22 \& \mathrm{ND}=3$ \&adjacent $=$ true\&locale $=$ en_EP \&FT $=$ D\&date $=20111$ 026\&CC $=\mathrm{CN} \& \mathrm{NR}=102224925 \mathrm{~A} \& \mathrm{KC}=\mathrm{A}$

http://worldwide.espacenet.com/publicationDetails/ \&adjacent $=$ true\&locale $=$ en_EP $\& F T=D \&$ date $=20110$ 928\&CC $=\mathrm{CN} \& \mathrm{NR}=102199547 \mathrm{~A} \& \mathrm{KC}=\mathrm{A}$

http://worldwide.espacenet.com/publicationDetails/ biblio? $\mathrm{DB}=$ worldwide. espacenet.com $\& \mathrm{II}=33 \& \mathrm{ND}=3$ \&adjacent $=$ true $\&$ locale $=$ en_EP $\& \mathrm{FT}=\mathrm{D} \&$ date $=20110$ $518 \& \mathrm{CC}=\mathrm{CN} \& \mathrm{NR}=102058728 \mathrm{~A} \& \mathrm{KC}=\mathrm{A}$ regulating immunity
http://worldwide.espacenet.com/publicationDetails/ biblio? $\mathrm{DB}=$ worldwide.espacenet.com $\& \mathrm{II}=38 \& \mathrm{ND}=3$ \&adjacent $=$ true\&locale $=$ en_EP \&FT $=$ D\&date $=20101$ $013 \& \mathrm{CC}=\mathrm{CN} \& \mathrm{NR}=101856370 \mathrm{~A} \& \mathrm{KC}=\mathrm{A}$
A

A 
Tab. 2 (continued)

\begin{tabular}{|c|c|c|c|}
\hline Inv. No. & Title of invention & Source of patent information regarding invention & $\mathrm{A} / \mathrm{B}$ \\
\hline 26 & $\begin{array}{l}\text { Method for preparing medicinal } \\
\text { liquor }\end{array}$ & $\begin{array}{l}\text { http://worldwide.espacenet.com/publicationDetails/ } \\
\text { biblio?DB=worldwide.espacenet.com\&II }=43 \& N D=3 \\
\text { \&adjacent=true\&locale=en_EP \&FT=D\&date }=20101 \\
\text { 124\&CC }=\mathrm{CN} \& N R=101892143 \mathrm{~A} \& \mathrm{KC}=\mathrm{A}\end{array}$ & A \\
\hline 27 & Age retardant for living organism & $\begin{array}{l}\text { http://patentscope.wipo.int/search/en/detail.jsf?docI } \\
\text { d=JP67349238\&recNum=34\&office=\&queryString= } \\
\text { ALLTXT\%3A\%28truffle\%29\&prevFilter=\&sortOptio } \\
\text { n=Relevance\&maxRec=385 }\end{array}$ & A \\
\hline 28 & $\begin{array}{l}\text { Agent for suppressing or } \\
\text { preventing oxidation of organism }\end{array}$ & $\begin{array}{l}\text { http://patentscope.wipo.int/search/en/detail.jsf?docI } \\
\text { d=JP67273260\&recNum=37\&office=\&queryString= } \\
\text { ALLTXT\%3A\%28truffle\%29\&prevFilter=\&sortOptio } \\
\text { n=Relevance\&maxRec=385 }\end{array}$ & A \\
\hline 29 & $\begin{array}{l}\text { Use of extracts of pezizaceae in } \\
\text { the prevention and/or treatment } \\
\text { of senile cataracts }\end{array}$ & $\begin{array}{l}\text { http://patentscope.wipo.int/search/en/detail.jsf?docI } \\
\text { d=US73487155\&recNum=105\&office=\&queryString } \\
\text { =ALLTXT\%3A\%28truffle\%29\&prevFilter=\&sortOpt } \\
\text { ion=Relevance\&maxRec=385 }\end{array}$ & A1 \\
\hline
\end{tabular}

Source: the author's eleboration based on Espacenet and Patentscope databases. Inv. No. - invention number; A - application; B - patent.

weight) of red tea, 5-50 parts (by weight) of truffles and 1-30 parts (by weight) of one or more of the following: mistletoe, medlar, chrysanthemum, honeysuckle flower, honey, ginseng, the stem and root of dwarf big blue lilyturf (Invention 24).

\section{Immunological resistance (Invention 1-5, 7, 10-11, 19, 21-22, 24-26)}

Pharmaceutical research has shown that a diet, which includes truffles, helps to increase resistance and fights fatigue. Foodstuffs most commonly rely on a combination of truffles and coffee beans (Invention 1, 3, 21-22) or [common] beans (Invention 3). In both cases, the weight ratio of the abovementioned components in the raw material should be $5-50$ parts truffles and 10-100 of coffee beans or [common] beans (Invention 1, 3).

Dairy products and beverages containing grapefruit juice provide further examples of applications of substances present in fungi. Milk products are based on milk and truffle fermentation wort or broth where both the volume and weight ratios of the raw material are (1-10) : (1-20). In beverages, the grapefruit juice volume ratio to the truffle fermentation broth in the raw material is $(1-10):(1-20)$ while the weight ratio to the truffle extract equals (1-10) : (1-20). It has been proven that both of these products have an anti-aging effect and increase somatic resistance (Invention 10-11). The aforementioned tea varieties containing truffle, lingzhi mushroom and black bean extracts or greater burdock and truffles also have a positive impact on immunological resistance (Invention $4,19)$. An effect on immunological resistance growth is also exhibited by pharmaceutical preparations, which contain a truffle extract alone, or in combination with other substances. Exemplary preparations can consist of truffles, vitamins and minerals in a weight ratio equal to $0.1-10$ parts, $0.005-3$ parts and $0.05-3$ parts, respectively, as well 
as combinations of truffles and Cordyceps sinensis (caterpillar mushrooms) in a weight ratio equal to $0.1-5$ parts and 1-10 parts, respectively (Invention 2, 25).

\section{Vigour growth (Invention 1, 9, 20, 25)}

It has been shown that dietary supplements containing Lepidium meyenii (maca), truffles and, optionally, scarlet caterpillar club mushroom influence the growth and strength of the body. The weight percentage of these ingredients should be $15-70 \%, 5-35 \%$ and $5-35 \%$, respectively. The supplement is prepared as follows: alcohol extraction of the active ingredient of dry or fresh maca root powder and preparation of truffle and scarlet caterpillar club fungus powder in accordance with generally accepted procedures. Purified powder derived from the fruit of Phyllanthus emblica (Indian gooseberry) or starch is auxiliary materials used in the making of the preparation (Invention 9, 20).

\section{Anti-aging benefits (Invention 10, 11, 27)}

Pharmacological studies have found that both milk products and beverages containing grapefruit juice in combination with truffles have anti-aging properties in addition to the impact on immunological resistance. In these studies, dairy products are based on milk and truffle fermentation wort while beverages are based on grapefruit juice and truffle fermentation wort or truffle extract (Invention 10-11).

\section{Other}

In addition, fungi-derived substances manifest a range of applications not mentioned above. These include but are not limited to:

(i) sedative action (truffles, lingzhi mushroom; Invention 4);

(ii) prevention and treatment of hormonal imbalances in women, premenopausal symptoms, senile urethritis and sleep disorders (truffles; Invention 6);

(iii) treatment of male sexual dysfunctions and prostate disorders (truffles; Invention 7);

(iv) alleviation of intolerance symptoms to milk such as diarrhoea or bloating and increased absorption of calcium from milk (truffles; Invention 13),

$(\boldsymbol{v})$ easing of rheumatic pains (truffles; Invention 19),

(vi) treatment and prevention of further development or recurrence of senile cataract (truffles; Invention 29).

\section{Conclusions}

The largest group of patents involves immunological resistance. It has been demonstrated that a diet containing truffles increases resistance and fights fatigue. There are a variety of applied combinations of truffles with coffee (Invention 1, 3, 21-22), beans (Invention 3), dairy products and beverages with a grapefruit-juice base (Invention 10-11). A mixture of truffles and grapefruit juice also has anti-aging properties. Immunological resistance is strengthened by compositions of tea varieties, which contain extracts of truffles, lingzhi mushroom and black beans or greater burdock and truffles (Invention 4, 19). Truffle extract is also effective when combined with vitamins or minerals; a combination of truffles and caterpillar mushrooms has beneficial applications (Invention 2, 26). 
The next group includes patents relating to increased vigour and vitality. These are dietary supplements containing maca, truffles and scarlet caterpillar club mushrooms, which are thought to affect bodily growth and strength. The formulation is also added to powdered fruit of Nepalese/Indian gooseberry or starch (Invention 9, 20).

Anticancer properties are shown by aqueous extracts of black truffle (T. melanosporum) and brown truffle (Invention 5).

Extracts containing truffles, lingzhi mushrooms and black beans are used in the treatment of cardiovascular and cerebrovascular diseases (Invention 4). A preparation containing greater burdock and truffles reduces both blood pressure and the level of blood fats (Invention 19). A similar action is demonstrated by edible oils containing vegetable oils or animal fats as well as truffle-derived oils. The volume ratio of the abovementioned fats/oils in the raw material is 1:0.1-1 (Invention 12). A preparation containing red tea and truffles also lowers blood fat levels (Invention 24).

Of the above patented solutions, those involving cancers and tumors (Patent 5), cardiovascular disease prevention and treatment (Invention 4, 19) and immuno-resistance enhancement (Invention 1-5, 7, 10-11, 19, 21-22, 24-26) should be highlighted for their applicability merits (practicability in use). The solutions are technologically quite simple and are easy to implement. A substantial disadvantage is that the raw material is expensive and, thus, highly reduces chances for implementation unless biotechnological processes are rolled out and put to use.

\section{Acknowledgments}

This work was partially financed by MNiSW under the initiative of "Grants for grants" - support for Polish coordinators in the research programs of the European Union on the preparation of the project: "Technology utilization in bio-geo environmental research: exemplary for innovative truffle biotechnology, domestication, economy and remote sensing (TUBER)", agreement No. 2515/GG 7. PR UE/2012/0 of 31.10.2012. Authors would like to express sincere thanks to Slobodan Bajagić (Croatia) for general idea for TUBER project. First author would like to thanks Mariusz Grzesiczak (Poland) for help in searching patent databases.

\section{Authors' contributions}

The following declarations about authors' contributions to the research have been made: patent databases research and analysis, draft of the manuscript: MG; analysis of therapeutic potential of truffles inventions: FR; characterization of truffles properties: JG; final writing of the manuscript: MG, FR, JG.

\section{References}

1. Intellectual Property Statistics Data Center [Internet]. 2014 [cited 2014 Feb 20]; Available from: http:// ipstatsdb.wipo.org/ipstatv2/ipstats/patentsSearch

2. Gajos M, Hilszczańska D. Research on truffles: Scientific journals analysis. Scientific Research and Essays 2013;8(38):1837 1847.

3. Hannan MA, Al-Dakan AA, Aboul-Enein HY, Al-Othaimeen AA. Mutagenic and antimutagenic factor(s) extracted from a desert mushroom using different solvents. Mutagenesis. 1989;4(2):111-114. http:dx.doi. org/10.1093/mutage/4.2.111

4. Murcia MA, Martinez-Tomé M, Jiménez AM, Vera AM, Honrubia M, Parras P. Antioxidant activity of edible fungi (truffles and mushrooms): losses during industrial processing. J Food Prot. 2002;65(10):1614 1622.

5. Al-Laith AAA. Antioxidant components and antioxidant/antiradical activities of desert truffle (Tirmania nivea) from various Middle Eastern origins. J Food Compost Anal. 2010;23(1):15-22. http://dx.doi. org/10.1016/j.jfca.2009.07.005

6. Amicarelli F, Bonfigli A, Colafarina S, Cimini AM, Pruiti B, Cesare P, et al. Glutathione dependent 
enzymes and antioxidant defences in truffles: organisms living in microaerobic environments. Mycol Res. 1999;103(12):1643-1648. http://dx.doi.org/10.1017/S0953756299008928

7. Villares A, García-Lafuente A, Guillamón E, Ramos Á. Identification and quantification of ergosterol and phenolic compounds occurring in Tuber spp. truffles. J Food Compost Anal. 2012;26(1-2):177-182. http://dx.doi.org/10.1016/j.jfca.2011.12.003

8. Janakat S, Nassar M. Hepatoprotective activity of desert truffle (Terfezia claveryi) in comparison with the effect of Nigella sativa in the rat. Pakistan Journal of Nutrition. 2010;9(1):52 56. http://dx.doi.org/10.3923/ pjn.2010.52.56

9. Janakat S, Al-Fakhiri S, Sallal AK. A promising peptide antibiotic from Terfezia claveryi aqueous extract against Staphylococcus aureus in vitro. Phytother Res. 2004;18(10):810 813.

10. Janakat SM, Al-Fakhiri SM, Sallal AKJ. Evaluation of antibacterial activity of aqueous and methanolic extracts of the truffle Terfezia claveryi against Pseudomonas aeruginosa. Saudi Med J. 2005;26(6):952-955.

11. Nazzaro F, Fratianni F, Picariello G, Coppola R, Reale A, Luccia AD. Evaluation of gamma rays influence on some biochemical and microbiological aspects in black truffles. Food Chem. 2007;103(2):344-354. http://dx.doi.org/10.1016/j.foodchem.2006.07.067

12. Hussan G, Al-Ruqaie IM. Occurrence in chemical composition, and nutritional value of truffles: overview. Pak J Biol Sci. 1999;2(2):510 514. http://dx.doi.org/10.3923/pjbs.1999.510.514

13. Fratianni F, Di Luccia A, Coppola R, Nazzaro F. Mutagenic and antimutagenic properties of aqueous and ethanolic extracts from fresh and irradiated Tuber aestivum black truffle: a preliminary study. Food Chem. 2007;102(2):471 474. http://dx.doi.org/10.1016/j.foodchem.2006.04.014

14. Stanikunaite R, Khan SI, Trappe JM, Ross SA. Cyclooxygenase-2 inhibitory and antioxidant compounds from the truffle Elaphomyces granulatus. Phytother Res. 2009;23(4):575 578. http://dx.doi.org/10.1002/ptr.2698

15. Tang YJ, Zhu LL, Liu RS, Li HM, Li DS, Mi ZY. Quantitative response of cell growth and Tuber polysaccharides biosynthesis by medicinal mushroom Chinese truffle Tuber sinense to metal ion in culture medium. Bioresour Technol. 2008;99(16):7606 7615. http://dx.doi.org/10.1016/j.biortech.2008.02.006

16. Ferreira ICFR, Vaz JA, Vasconcelos MH, Martins A. Compounds from wild mushrooms with antitumor potential. Anticancer Agents Med Chem. 2010;10(5):424-436. http://dx.doi.org/10.2174/1871520611009050424

17. Ng TB, Wong JH. Fungal proteins with antiproliferative and anticancer activities. Protein Pept Lett. 2013;20(4):433-438. http://dx.doi.org/10.2174/0929866511320040007

18. Jinming G, Lin H, Jikai L. A novel sterol from Chinese truffles Tuber indicum. Steroids. 2001;66(10):771-775. http://dx.doi.org/10.1016/S0039-128X(01)00105-2

19. Martin F, Kohler A, Murat C, Balestrini R, Coutinho PM, Jaillon O., et al. Perigord black truffle genome uncovers evolutionary origins and mechanisms of symbiosis. Nature. 2010;464:1033 1038. http://dx.doi. org/10.1038/nature08867

20. Murat C, Riccioni C, Belfiori B, Cichocki N, Labbé J, Morin E, et al. Distribution and localization of microsatellites in the Perigord black truffle genome and identification of new molecular markers. Fungal Genet Biol. 2011;48(6):592 601. http://dx.doi.org/10.1016/j.fgb.2010.10.007

21. Lacourt I, Duplessis S, Abbà S. Isolation and characterization of differentially expressed genes in the mycelium and fruiting body of Tuber borchii. J Appl Environ Microbiol. 2002;68(9):4574 4582.

22. Splivallo R, Ottonello S, Mello A, Karlovski P. Truffle volatiles: from chemical ecology to aroma biosynthesis. New Phytol. 2011;189(3):688 699.

23. Bolchi A, Ruotolo R, Marchini G, Vurro E, di Toppi LS, Kohler A, et al. Genome-wide inventory of metal homeostasis-related gene products including a functional phytochelatin synthase in the hypogeous mycorrhizal fungus Tuber melanosporum. Fungal Genet Biol. 2011;48(6):573 584. http://dx.doi. org/10.1016/j.fgb.2010.11.003

24. Navarro-Ródenas A, Ruíz-Lozano JM, Kaldenhoff R, Morte A. The Aquaporin TcAQP1 of the desert truffle Terfezia claveryi is a membrane pore for water and $\mathrm{CO}_{2}$ transport. Mol Plant Microbe Interact. 2012;25(2):259 266. http://dx.doi.org/10.1094/MPMI-07-11-0190

25. Tang Y, Li HM, Tang YJ. Comparison of sterol composition between Tuber fermentation mycelia and natural fruiting bodies. Food Chem. 2012;132(3):1207 1213. http://dx.doi.org/10.1016/j.foodchem.2011.11.077 
26. White MJ. esp@cenet Europe’s Network of Patent Databases. Issues Sci Technol Lib. 2006;47. http:// dx.doi.org/10.5062/F4F47M2H

27. Gajos M. Opis patenowy jako źródło informacji. Katowice: University of Silesia; 2000.

28. Handbook on industrial property information and documentation [Internet]. 2013 [cited 2013 Dec 19]; Available from: http://www.wipo.int/standards/en/part_03_standards.html

29. International patent classification - version 2013. Guide [Internet]. 2013 [cited 2013 Dec 15]; Available at: http://www.iponz.govt.nz/cms/iponz/latest-news/expired-items/international-patent-classification-2013 